\title{
Comparison of bone tissue trace-element concentrations and mineral density in osteoporotic femoral neck fractures and osteoarthritis
}

This article was published in the following Dove Press journal:

Clinical Interventions in Aging

18 August 2014

Number of times this article has been viewed

\author{
Fatih Karaaslan' \\ Mahmut Mutlu² \\ Musa Uğur Mermerkaya' \\ Sinan Karaoğlu ${ }^{3}$ \\ Șerife Saçmaci ${ }^{4}$ \\ Șenol Kartal ${ }^{4}$ \\ 'Department of Orthopaedics \\ and Traumatology, Faculty of Medicine, \\ Bozok University, Yozgat, ${ }^{2}$ Department \\ of Orthopaedics and Traumatology, \\ Faculty of Medicine, Erciyes University, \\ ${ }^{3}$ Department of Orthopaedics \\ and Traumatology, Memorial Kayseri \\ Hospital, ${ }^{4}$ Department of Chemistry, \\ Faculty of Sciences, Erciyes University, \\ Kayseri, Turkey
}

Purpose: This study examined the role of trace elements in osteoporosis by comparing the trace-element concentrations in bone and the radiographic bone density and bone mineral density (BMD) of patients with osteoporotic femur fractures and osteoarthritis.

Patients and methods: The study enrolled 30 patients operated on for proximal femoral fractures after falls, and another 30 patients undergoing hip arthroplasty at the same center for hip osteoarthritis. Bone samples were obtained during the surgical procedures. The density of the bone samples was assessed using computed tomography and the Hounsfield scale. The levels of $\mathrm{Ca}(\mathrm{II}), \mathrm{Mg}(\mathrm{II})$, and other trace elements in the bone samples were determined using flame atomic absorption spectrometry and inductively coupled plasma mass spectrometry. In addition, BMD, Z-scores, and T-scores were measured in the unaffected hips of all patients using dual-energy X-ray absorptiometry.

Results: Magnesium $(1,908 \pm 507$ versus $2,540 \pm 435, P<0.05)$, calcium $(10.4 \pm 3.5$ versus $13.9 \pm 3.7, P<0.05)$, and zinc $(2,342 \pm 1,252$ versus $3,145 \pm 1,604, P<0.05) \mu \mathrm{g} \mathrm{g}^{-1}$, levels were significantly lower in the bone samples in the fracture group. The groups did not differ in the other biochemical parameters. All dual-energy X-ray absorptiometry findings were significantly worse in the fracture group than in the osteoarthritis group. However, the groups did not differ in femoral neck density assessed radiologically using the Hounsfield scale. The following parameters were negatively correlated with age: magnesium, $r=-0.436, P<0.001$; calcium, $r=-0.331, P=0.01$; T-score, $r=-0.381, P=0.003$; $\mathrm{Z}$-score, $r=-0.267, P=0.043$; and BMD, $r=-0.365, P=0.004$.

Conclusion: $\mathrm{Ca}(\mathrm{II}), \mathrm{Mg}(\mathrm{II})$, and $\mathrm{Zn}$ (II) appear to play important roles in bone breakdown/ synthesis. Further studies of the roles of trace elements in the etiology and treatment of osteoporosis are warranted. We found decreased bone levels of $\mathrm{Ca}, \mathrm{Mg}$, and $\mathrm{Zn}$ in patients with osteoporotic fractures compared to subjects with osteoarthritis.

Keywords: osteoporosis, trace elements, calcium, magnesium, zinc

\section{Introduction}

Osteoporosis is a metabolic bone disease characterized by increased bone fragility due to decreased bone mass and altered bone microstructure, and is associated with high mortality, morbidity, and treatment costs. ${ }^{1}$ The World Health Organization reported that $35 \%$ of the women in the US older than 65 years had osteoporosis in $1994 .^{2}$ The most dreaded complication of osteoporosis is bone fracture, particularly of the hip. In 1990, 1.3 million hip fractures were reported worldwide, and this figure is expected to double by 2025 and to reach 4.5 million by $2050 .^{3}$ The relationship between trace elements and the etiology of osteoporosis is intriguing. The role of alterations in such
Correspondence: Fatih Karaaslan Department of Orthopaedics and Traumatology, Faculty of Medicine, Bozok University, 18 Madrasa Adnan Menderes Boulevard, Yozgat 66200, Turkey

Tel +903542127060

Fax+903542140612

Email fkaraaslan@gmail.com 
trace elements as magnesium, copper, zinc, manganese, cadmium, and lead in the development of osteoporosis and the effects of treating mineral profiles on osteoporosis have yet to be fully elucidated.

Magnesium, a ubiquitous element in various organ systems, is thought to play a role in the mineral metabolism of both soft and hard tissues. It mimics the actions of $\mathrm{Ca}$ in transport and mineralization processes, and is required for normal $\mathrm{Ca}$ absorption. Its roles in bone metabolism and in the development of metabolic bone disease are not fully understood. Furthermore, whether $\mathrm{Mg}$ deficiency results in osteoporosis is unknown, with conflicting reports on the $\mathrm{Mg}$ content of osteoporotic bone. ${ }^{4}$

Zinc is a component of the cell nucleus, mitochondria, cytoplasm, and plasma membrane, and is involved in the synthesis of several metalloenzymes. ${ }^{5-7}$ It is an essential component of enzymes involved in transcription, translation, and nucleic acid synthesis, which have important roles in the metabolic activity of bone. ${ }^{5}$ In addition, bone zinc content is decreased postmenopausally, and with aging and skeletal unloading, suggesting a role in bone disorders. ${ }^{8}$

Therefore, this study compared the trace-element concentrations in bone and the radiographic bone density and bone mineral density (BMD) of two groups of patients: those undergoing partial hip prosthesis due to an osteoporotic proximal femoral fracture, and those undergoing total hip arthroplasty due to osteoarthritis.

\section{Patients and methods}

\section{Patients}

This study included 30 patients operated on at the Orthopedics and Traumatology Department of Erciyes University Medical School between December 2008 and December 2009 for osteoporotic proximal femur fractures after falls, consisting of nine men 70-85 mean \pm SD (72.8 \pm 6.08$)$ years

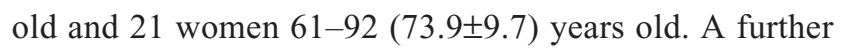
30 patients undergoing hip arthroplasty in the same center for primary hip osteoarthritis consisted of nine men

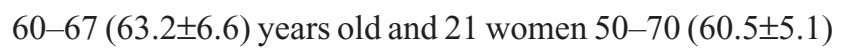
years old. The females in both groups were postmenopausal. A history of high-impact trauma, previous treatment for osteoporosis (bisphosphonates, raloxifene, calcitonin, hormone-replacement therapy, vitamin D and its derivatives, etc), systemic steroid use, malignancy associated with bone metastases, and other secondary causes of osteoporosis comprised the exclusion criteria. The study protocol was approved by the Erciyes University Local Ethics Committee 2008/608, December 2, 2008).

\section{Surgical sampling}

All patients had prosthetic hip replacements. During the surgical procedure, the soft tissues surrounding the femoral head were displaced, after which the femoral head and neck were extracted from the acetabulum manually in all patients to avoid any metal contamination. Then, the sample was cleaned using $1,000 \mathrm{~mL}$ of physiological saline and stored at $-70^{\circ} \mathrm{C}$ for biochemical and radiological examinations.

\section{Assessments}

\section{Radiological assessment of bone tissue samples}

All of the frozen samples from the patient and control groups (ie, the proximal femur bone samples) were examined with 1.25 mm-thick cross sections using a LightSpeed ${ }^{\circledR}$ 16-multislice computed tomography device (GE Healthcare, Waukesha, WI, USA) in a single session. Reformatted images were obtained with an Infinitt (Phillipsburg, NJ, USA) picture-archiving and communication-system viewer. The tomographic densities were calculated using the Hounsfield scale at three different points limited to spongy bone. With this scale, the attenuation factor for the X-rays diffusing through the tissues is calculated numerically to represent each pixel. The numbers are arranged on a scale between $+1,000$ and $-1,000$ where the attenuation value of water is zero.

\section{Biochemical assessment of bone tissue samples}

The bone specimens obtained from the patients were transferred to the laboratory and dried in an oven at $110^{\circ} \mathrm{C}$ until a constant weight was reached. This procedure was used to determine the water content (gravimetric method). Dried samples were ground in an agate mortar. Bone material was mineralized using wet digestion in a Velp Scientifica mineralizer (Usmate Velate, Italy). ${ }^{9,10}$ The analytical ash sample (approximately $1 \mathrm{~g}$ ) was digested in $2 \mathrm{~cm}^{3}$ of spectrally pure $\mathrm{HNO}_{3}$ (V) (Suprapur ${ }^{\circledR}$; Merck Millipore, Billerica, MA, USA). The bone samples were dissolved in $10 \mathrm{~mL}$ of concentrated $\mathrm{HNO}_{3}$ using a microwave oven. Then, the samples were diluted to a volume of $25 \mathrm{~mL}$ using distilled water for inductively coupled plasma mass spectrometry (ICP-MS).

\section{Determination}

A PerkinElmer (Norwalk, CT, USA) model A Analyst 800 flame atomic absorption spectrometer equipped with a deuterium background-correction system and an airacetylene burner was used to determine $\mathrm{Ca}$ (II) and $\mathrm{Mg}$ (II) at wavelengths of 422.7 and $285.2 \mathrm{~nm}$, respectively, using standard working parameters: spectral bandwidth $0.2 \mathrm{~nm}$, 
acetylene flow rate $1.4 \mathrm{~L} \cdot \mathrm{min}^{-1}$, and nebulizer flow rate $10 \mathrm{~mL} \cdot \mathrm{min}^{-1}$.

Then, $100 \mu \mathrm{L}$ of each the dissolved bone samples was diluted using $10 \mathrm{~mL}$ of $1 \mathrm{M} \mathrm{HNO}_{3}$ for magnesium determination. To measure calcium, $50 \mu \mathrm{L}$ of $2 \%$ lanthanum solution was added to $50 \mu \mathrm{L}$ of the dissolved bone sample to eliminate the risk of a faulty measurement, due to the high phosphate content of the bone. Then, the volumes were made up to $10 \mathrm{~mL}$ for flame atomic absorption spectrometry.

For ICP-MS, an Agilent 7500A (Agilent Technologies, Santa Clara, CA, USA) was used with a Consort (Turnhout, Belgium) model C533 pH meter combined with a glass electrode. For each dissolved bone sample, a $10 \mathrm{~mL}$ sample was obtained and neutralized using $1 \mathrm{M} \mathrm{NaOH}$. Then, the $\mathrm{pH}$ was adjusted to 4.5 with a magnetic mixer following an optimized procedure. Next, $1 \mathrm{~mL}$ of $1 \%$ ammonium pyrrolidine dithiocarbamate (APDC) solution was added to each sample and mixed for 10 minutes. The sample solution was then transferred to a separatory funnel. The metal-APDC chelate was extracted by shaking the mixture for 2 minutes with $5+5 \mathrm{~mL}$ of methyl isobutyl ketone. The two phases were allowed to separate, and then the organic phase was transferred to another separatory funnel. To this organic phase, $10 \mathrm{~mL}$ of $2 \mathrm{M} \mathrm{HNO}_{3}$ was added and mixed thoroughly, and then the metal-APDC chelate was back-extracted from the methyl isobutyl ketone into $2 \mathrm{M} \mathrm{HNO}_{3}$. To determine the metal concentrations, the aqueous phase was analyzed using ICP-MS. For each sample, two or three repetitions were performed, and statistical analysis was used to average the data, which were expressed as micrograms per gram dry weight (dw). In order to verify the accuracy of the procedure, the method for certified reference materials was used (CRM1486). ${ }^{10}$ The results are shown in Tables 1 and 2 .

\section{Bone mineral-density measurement}

In both patient groups, BMD, Z-scores, and T-scores were measured in the unaffected hip with dual-energy X-ray absorptiometry (DEXA) using a QDR-4500A (Hologic, Bedford, MA, USA) within the first week after surgery.

Table I Analysis of CRM-SRM I486 (bone meal) ( $\mu \mathrm{g} \cdot \mathrm{g}^{-1}$ dry weight)

\begin{tabular}{lll}
\hline Element & Certified & Measured \\
\hline $\mathrm{Ca}$ & $26.58 \pm 0.24$ & $26.46 \pm 1.12$ \\
$\mathrm{~Pb}$ & $1.335 \pm 0.014$ & $1.32 \pm 0.1$ \\
$\mathrm{~K}$ & $412 \pm 4$ & $414 \pm 5$ \\
$\mathrm{Cr}$ & $264 \pm 7$ & $265 \pm 5$ \\
$\mathrm{Zn}$ & $147 \pm 16$ & $147 \pm 7$ \\
\hline
\end{tabular}

Table 2 Recovery rates (\%) $(\mathrm{n}=3)$

\begin{tabular}{llll}
\hline$\mu \mathrm{g} \cdot \mathrm{mL}^{-1}$ & $\mathrm{Cu}$ & $\mathrm{Zn}$ & $\mathrm{Pb}$ \\
\hline 0.5 & $97 \pm \mathrm{I}$ & $98 \pm 2$ & $97 \pm 2$ \\
1.0 & $98 \pm 2$ & $97 \pm 1$ & $98 \pm \mathrm{I}$ \\
2.0 & $99 \pm \mathrm{I}$ & $100 \pm 2$ & $98 \pm 1$ \\
\hline
\end{tabular}

DEXA was performed with the patient in a supine position, with the hip joint rotated $15^{\circ}$ internally. Osteophytes and sclerotic margins were excluded from the measurement.

\section{Statistical analyses}

SPSS 21.0 (IBM, Armonk, NY, USA) was used for the statistical analyses. Descriptive statistics are presented as means and standard deviation. The homogeneous distribution of the groups was tested using the KolmogorovSmirnov and Shapiro-Wilk tests. Variables with normal distributions were evaluated using the independent $t$-test, while those with abnormal distributions were tested using the Mann-Whitney $U$ test. The associations among variables were assessed using Spearman's and Pearson's correlation analyses. A $P$-value $<0.05$ was considered to indicate statistical significance.

\section{Results}

The fracture group was significantly older than the osteoarthritis group (mean age $77.4 \pm 8.6$ versus $64.6 \pm 6.1$ years, $P<0.001)$. The groups did not differ with regard to sex distribution (male:female ratio 9:21 in both groups, $P=1.000$ ). The patients in the fracture group all underwent a partial hip arthroplasty; this was for intertrochanteric fractures in ten patients and for femoral neck fractures in 20 patients. All patients in the osteoarthritis group underwent total hip arthroplasty.

The two groups are compared in Table 3. Of the biochemical parameters, the tissue levels of magnesium $\left(1.908 \pm 507 \mu \mathrm{g} \cdot \mathrm{g}^{-1} \mathrm{dw}\right.$ versus $\left.2,540 \pm 435 \mu \mathrm{g} \cdot \mathrm{g}^{-1} \mathrm{dw}, P<0.05\right)$, calcium $\left(10.4 \pm 3.5 \mu \mathrm{g} \cdot \mathrm{g}^{-1} \mathrm{dw}\right.$ versus $13.9 \pm 3.7 \mu \mathrm{g} \cdot \mathrm{g}^{-1} \mathrm{dw}$, $P<0.05)$, and zinc $\left(2,342 \pm 1,252 \mu \mathrm{g} \cdot \mathrm{g}^{-1} \mathrm{dw}\right.$ versus $\left.3,145 \pm 1,604 \mu \mathrm{g} \cdot \mathrm{g}^{-1} \mathrm{dw}, P<0.05\right)$ were significantly lower in the fracture group, whereas the groups did not differ with regard to the other biochemical parameters.

All of the DEXA findings were significantly worse in the fracture group compared to the osteoarthritis group (T-score, $-3 \pm 1.2$ versus $-1.1 \pm 0.8, P<0.05$; Z-score, $-1.13 \pm 1.2$ versus $0.05 \pm 0.8, P<0.05$; and $\mathrm{BMD}, 0.6 \pm 0.1$ versus $0.8 \pm 0.09$, $P<0.001)$; however, the groups did not differ radiologically in femoral neck density assessed using the Hounsfield scale (Table 4). According to the Spearman analysis, $\mathrm{Ca}(r=0.49)$, 
Table 3 Comparison of the two study groups

\begin{tabular}{|c|c|c|c|c|c|}
\hline \multicolumn{3}{|c|}{$\begin{array}{ll}\text { Parameter } & \text { Fracture group }(n=30) \\
\end{array}$} & \multicolumn{2}{|c|}{ Osteoarthritis group $(n=30)$} & \multirow[t]{2}{*}{$P$ for difference } \\
\hline Biochemical as & of tissue sa & & & & \\
\hline \multirow[t]{4}{*}{ Magnesium (Mg) } & $A M \pm S D$ & $1,908 \pm 507$ & $A M \pm S D$ & $2,540 \pm 435$ & $<0.05^{\mathrm{b}}$ \\
\hline & Median & $2,183.3$ & Median & $2,566.7$ & \\
\hline & Range & $938-2,818$ & Range & $1,637-3,357$ & \\
\hline & $\mathrm{CV}$ & 26.57 & $\mathrm{CV}$ & 17.14 & \\
\hline \multirow[t]{4}{*}{ Calcium (Ca) } & $A M \pm S D$ & $10.4 \pm 3.5$ & $A M \pm S D$ & $13.9 \pm 3.7$ & $<0.05^{c}$ \\
\hline & Median & 9.7 & Median & 12.8 & \\
\hline & Range & $4.8-21.0$ & Range & $9.3-21.0$ & \\
\hline & $\mathrm{CV}$ & 34.9 & $\mathrm{CV}$ & 26.8 & \\
\hline \multirow[t]{4}{*}{ Aluminum (Al) } & $A M \pm S D$ & $354 \pm 189$ & $A M \pm S D$ & $376 \pm 223$ & $0.657^{c}$ \\
\hline & Median & 310 & Median & 352.8 & \\
\hline & Range & $125-958$ & Range & $78-1,096$ & \\
\hline & $\mathrm{CV}$ & 53.2 & $\mathrm{CV}$ & 168.5 & \\
\hline \multirow[t]{4}{*}{ Potassium (K) } & $A M \pm S D$ & $124 \pm 388$ & $A M \pm S D$ & $119 \pm 484$ & $0.215^{c}$ \\
\hline & Median & 0 & Median & 0 & \\
\hline & Range & $0-1,878$ & Range & $0-2,581$ & \\
\hline & $\mathrm{CV}$ & 313 & $\mathrm{CV}$ & 405.3 & \\
\hline \multirow[t]{4}{*}{ Vanadium (V) } & $A M \pm S D$ & $20 \pm 46$ & $A M \pm S D$ & $22 \pm 43$ & $0.832^{c}$ \\
\hline & Median & 0 & Median & 0 & \\
\hline & Range & $0-190$ & Range & $0-167$ & \\
\hline & $\mathrm{CV}$ & 231.3 & $\mathrm{CV}$ & 191.3 & \\
\hline \multirow[t]{4}{*}{ Chromium (Cr) } & $A M \pm S D$ & $14 \pm 38$ & $A M \pm S D$ & $10 \pm 32$ & $0.669^{c}$ \\
\hline & Median & 0 & Median & 0 & \\
\hline & Range & $0-152$ & Range & $0-134$ & \\
\hline & $\mathrm{CV}$ & 283 & $\mathrm{CV}$ & 337 & \\
\hline \multirow[t]{4}{*}{ Manganese (Mn) } & $A M \pm S D$ & $693 \pm 765$ & $A M \pm S D$ & $728 \pm 728$ & $0.569^{c}$ \\
\hline & Median & 450 & Median & 545 & \\
\hline & Range & $0-2,710$ & Range & $0-2,803$ & \\
\hline & $C V$ & 110.4 & $\mathrm{CV}$ & 100 & \\
\hline \multirow[t]{4}{*}{ Iron $(\mathrm{Fe})$} & $A M \pm S D$ & $|82 \pm 24|$ & $A M \pm S D$ & $108 \pm 107$ & $0.460^{c}$ \\
\hline & Median & 77.1 & Median & 72.2 & \\
\hline & Range & II.4-I,027 & Range & $10.3-378$ & \\
\hline & $\mathrm{CV}$ & 110.4 & CV & 98.8 & \\
\hline \multirow[t]{4}{*}{ Nickel (Ni) } & $A M \pm S D$ & $95 \pm 212$ & $A M \pm S D$ & $125 \pm 215$ & $0.591^{c}$ \\
\hline & Median & 0 & Median & 0 & \\
\hline & Range & $0-960$ & Range & $0-770$ & \\
\hline & $\mathrm{CV}$ & 223.3 & $\mathrm{CV}$ & 172.5 & \\
\hline \multirow[t]{4}{*}{ Zinc (Zn) } & $A M \pm S D$ & $2,342 \pm 1,252$ & $A M \pm S D$ & $3,145 \pm 1,604$ & $<0.05^{\mathrm{b}}$ \\
\hline & Median & 2,564 & Median & 3,391 & \\
\hline & Range & $0-4,305$ & Range & $0-6,004$ & \\
\hline & $C V$ & 53.5 & $\mathrm{CV}$ & 51 & \\
\hline \multirow[t]{4}{*}{ Arsenic (As) } & $A M \pm S D$ & $10 \pm 18$ & $A M \pm S D$ & $20 \pm 45$ & $0.932^{c}$ \\
\hline & Median & 3.9 & Median & 1.15 & \\
\hline & Range & $0-94$ & Range & $0-220$ & \\
\hline & $\mathrm{CV}$ & 181 & $\mathrm{CV}$ & 227.2 & \\
\hline \multirow[t]{4}{*}{ Selenium (Se) } & $A M \pm S D$ & $42 \pm 103$ & $A M \pm S D$ & $33 \pm 44$ & $0.434^{c}$ \\
\hline & Median & 0.5 & Median & 20.2 & \\
\hline & Range & $0-533$ & Range & $0-183$ & \\
\hline & $\mathrm{CV}$ & 244.7 & $\mathrm{CV}$ & $135 . \mid$ & \\
\hline \multirow[t]{4}{*}{ Silver (Ag) } & $A M \pm S D$ & $637 \pm 987$ & $A M \pm S D$ & $517 \pm 383$ & $0.322^{c}$ \\
\hline & Median & 234.3 & Median & 488.7 & \\
\hline & Range & $0-4,638$ & Range & $0-1,420$ & \\
\hline & $C V$ & 154.9 & $\mathrm{CV}$ & 74 & \\
\hline \multirow[t]{4}{*}{ Antimony (Sb) } & $A M \pm S D$ & $19 \pm 36$ & $A M \pm S D$ & $3 I \pm 5 I$ & $0.640^{c}$ \\
\hline & Median & 5.3 & Median & 5.7 & \\
\hline & Range & $0-188$ & Range & $0-165$ & \\
\hline & $\mathrm{CV}$ & 188.7 & $\mathrm{CV}$ & 165.7 & \\
\hline
\end{tabular}


Table 3 (Continued)

\begin{tabular}{|c|c|c|c|c|c|}
\hline \multirow{2}{*}{$\frac{\text { Parameter }}{\text { Barium (Ba) }}$} & \multicolumn{2}{|c|}{ Fracture group $(n=30)$} & \multicolumn{2}{|c|}{ Osteoarthritis group $(n=30)$} & \multirow{2}{*}{$\begin{array}{l}P \text { for difference } \\
0.94 I^{c}\end{array}$} \\
\hline & $\mathrm{AM} \pm \mathrm{SD}$ & $653 \pm 695$ & $\mathrm{AM} \pm \mathrm{SD}$ & $661 \pm 692$ & \\
\hline & Median & 528.5 & Median & 524 & \\
\hline & Range & $26.4-3,831$ & Range & $64-3,554$ & \\
\hline & $\mathrm{CV}$ & 106.3 & $\mathrm{CV}$ & 104.7 & \\
\hline \multirow[t]{4}{*}{ Lead $(\mathrm{Pb})$} & $A M \pm S D$ & $55 \pm 92$ & $\mathrm{AM} \pm \mathrm{SD}$ & $28 \pm 57$ & $0.189^{c}$ \\
\hline & Median & 0 & Median & 0 & \\
\hline & Range & $0-3 \mid 4$ & Range & $0-207$ & \\
\hline & CV & 167.9 & CV & 200.7 & \\
\hline
\end{tabular}

Notes: ${ }^{a}$ Tissue levels are expressed as micrograms per gram of dry weight; ${ }^{b}$ Student's t-test; 'Mann-Whitney $U$ test. Abbreviations: AM, arithmetic mean; SD, standard deviation; CV, coefficient of variation.

$\mathrm{Zn}(r=0.26), \mathrm{Mg}(r=0.56), \mathrm{T}$-scores $(r=0.74), \mathrm{Z}$-scores $(r=0.56)$, and BMD $(r=0.67)$ were negatively correlated with the presence of fracture $(P<0.05)$.

When the two groups were pooled and a correlation analysis was performed, the following parameters were significantly and negatively correlated with age: magnesium, $r=-0.436, P<0.001$; calcium, $r=-0.331, P=0.01$; T-score, $r=-0.381, P=0.003$; Z-score, $r=-0.267, P=0.044$; and BMD, $r=-0.365, P=0.004$. Tissue magnesium levels were significantly correlated with T-scores $(r=0.363, P=0.004)$ and BMD ( $r=0.309, P=0.016)$. Similarly, tissue calcium levels were correlated with T-scores $(r=0.302, P=0.019)$ and BMD $(r=0.256, P=0.049)$. Though there was a correlation between $\mathrm{T}$-scores and $\mathrm{Zn}$, it was not significant.

When sex effects were evaluated, $\mathrm{Ca}, \mathrm{Mg}, \mathrm{T}$-scores, $\mathrm{Z}$-scores, and BMD were significantly lower in the fracture group for females, while $\mathrm{Zn}$ levels were included in this list for males. In the fracture group, females had significantly lower $\mathrm{Zn}$ levels than males $(t=-2.146, P=0.041)$; interestingly, Mn levels were significantly higher in females $(U=43$, $P=0.002$ ).

Although the relationship between $\mathrm{Ca} / \mathrm{Mg}$ and $\mathrm{Zn}$ levels ( $r=0.015, P>0.05$ ) was not significant, there was a strong correlation between $\mathrm{Ca} / \mathrm{Mg}(r=0.844)$ levels in the fracture group and $\mathrm{Ca} / \mathrm{Zn}(r=0.32)$ and $\mathrm{Zn} / \mathrm{Mg}(r=0.438)$ when evaluated in both groups. In the Spearman analysis, despite positive correlations between $\mathrm{Fe}, \mathrm{K}, \mathrm{Cr}, \mathrm{Pb}$, and $\mathrm{As}$ levels and the presence of fracture, they were not significant $(P>0.05)$.

\section{Discussion}

This study compared the bone mineral concentrations, mineral density, and radiological density in patients with femoral fractures or osteoarthritis. As expected, patients with bone fractures had lower BMD, T-scores, and Z-scores than those with osteoarthritis. Similarly, the calcium concentration in the bones with fractures was lower. In addition, the concentrations of a large number of trace elements were examined, with $\mathrm{Ca}, \mathrm{Mg}$, and $\mathrm{Zn}$ levels being lower in cases with femoral fractures, as shown by DEXA. However, there were no significant differences in the other trace element levels and tomographic Hounsfield-unit levels. We are convinced that this situation would change using quantitative computed tomography and increasing the number of subjects.

Several clinical studies have reported chronic Mg deficiency in postmenopausal women with osteoporosis. ${ }^{11-16}$ Nielsen found a reduced concentration of ionized calcium due to $\mathrm{Mg}$ deficiency, and concluded that $\mathrm{Mg}$ is required for optimal Ca metabolism and that elderly males and postmenopausal females need $\mathrm{Mg}$ to prevent the severe bone loss that is common in these populations. ${ }^{17}$ Increased numbers of osteoclasts, decreased osteoblastic function, and accelerated bone mineralization have been observed in association with magnesium

Table 4 Comparison of the two study groups in terms of density

\begin{tabular}{|c|c|c|c|c|c|}
\hline Parameter & \multicolumn{2}{|c|}{ Fracture group $(n=30)$} & \multicolumn{2}{|c|}{ Osteoarthritis group $(n=30)$} & $P$ for difference \\
\hline \multicolumn{6}{|c|}{ Radiological assessment of tissue samples } \\
\hline Femoral neck density ${ }^{a}$ & $A M \pm S D$ & $186.7 \pm 139.3$ & $\mathrm{AM} \pm \mathrm{SD}$ & $226.1 \pm 106.4$ & $0.224^{b}$ \\
\hline \multicolumn{6}{|c|}{ DEXA measurements of the contralateral hip } \\
\hline T-score & $\mathrm{AM} \pm \mathrm{SD}$ & $-3.0 \pm 1.2$ & $\mathrm{AM} \pm \mathrm{SD}$ & $-1.1 \pm 0.8$ & $<0.05^{c}$ \\
\hline Z-score & $\mathrm{AM} \pm \mathrm{SD}$ & $-1.13 \pm 1.2$ & $\mathrm{AM} \pm \mathrm{SD}$ & $0.1 \pm 0.8$ & $<0.05^{c}$ \\
\hline $\mathrm{BMD}\left(\mathrm{g} / \mathrm{cm}^{2}\right)$ & $\mathrm{AM} \pm \mathrm{SD}$ & $0.6 \pm 0.1$ & $\mathrm{AM} \pm \mathrm{SD}$ & $0.8 \pm 0.1$ & $<0.05^{\mathrm{b}}$ \\
\hline
\end{tabular}

Notes: aBased on the Hounsfield scale; 'Student's t-test; 'Mann-Whitney $U$ test.

Abbreviations: AM, arithmetic mean; SD, standard deviation; DEXA, dual-energy X-ray absorptiometry; BMD, bone mineral density. 
deficiency, suggesting that altered metabolic turnover and mineralization in bone causes bone fragility. ${ }^{18,19}$ In our study, subjects with femoral neck fractures had significantly lower bone $\mathrm{Mg}$ concentrations than those with osteoarthritis, and there was a negative correlation between age and $\mathrm{Mg}$ content in the overall study group. In addition, there was a positive correlation between Mg levels and BMD. Collectively, these data support the suggestions that low Mg increases the risk of fracture.

Calhoun reported increased zinc uptake during bone healing in rats. ${ }^{20}$ In experimental animal models, Zn deficiency has been associated with altered osteoblastic activity and decreased synthesis of collagen, chondroitin sulfate, and alkaline phosphatase. ${ }^{21}$ Despite conflicting data on the bone zinc concentration in patients with osteoporosis, there is a consensus regarding the important role of $\mathrm{Zn}$ in bone metabolism. ${ }^{22-25}$ Steidl and Ditmar reported lower Zn concentrations in patients with senile or postmenopausal osteoporosis, suggesting an association between zinc and magnesium in patients with osteoporosis. ${ }^{26}$ To investigate the role of $\mathrm{Zn}$ in osteoporosis, Matarán Pérez et al explored the relationship between the oral intake of $\mathrm{Zn}$ through nutrition and urinary and serum levels of $\mathrm{Zn}$, finding no significant difference in serum $\mathrm{Zn}$ levels between osteoporotic and nonosteoporotic subjects. ${ }^{27}$ A new finding - that the zinc status of osteoporotic patients is significantly different from that of patients with osteoarthritis - supports the view that these two conditions rarely occur in the same individual. ${ }^{28}$ In our study, the $\mathrm{Zn}$ content of bone was marginally significantly lower in fracture patients compared to osteoarthritis patients, but there was no correlation between $\mathrm{Zn}$ and BMD. Considering the contradictory data, further work is necessary to better define the role of $\mathrm{Zn}$ in the development of osteoporosis.

Several studies have looked at the association between trace-element intake and bone parameters, in addition to the possible benefits of supplementation with trace elements. In a study of 159 females, Angus et al found that forearm BMD was positively correlated with $\mathrm{Fe}, \mathrm{Zn}$, and $\mathrm{Mg}$ intake, and suggested that nutritional factors other than calcium play a role in the formation of bone mass. ${ }^{29}$ Hyun et al reported a positive correlation between dietary $\mathrm{Zn}$ intake, plasma $\mathrm{Zn}$ concentration, and BMD. ${ }^{30}$ Similarly, supplementation with $\mathrm{Zn}$ and $\mathrm{Cu}$ has been found to decrease bone loss in postmenopausal females, and supplementation with Ca paradoxically resulted in reduced absorption of $\mathrm{Zn}$ and $\mathrm{Cu} .{ }^{31,32}$ Cournot and Hercberg underscored the role of trace elements in the prevention and treatment of osteoporosis, focusing on the importance of consuming $\mathrm{Mg}$-rich nutrients, as well as milk and milk products, starting from childhood. ${ }^{33}$ Tranquilli et al reported lower intakes of $\mathrm{Ca}, \mathrm{P}$, and $\mathrm{Mg}$ in 194 osteoporotic females compared to controls, and found a correlation between these elements and BMD. ${ }^{34}$ They pointed out the importance of appropriate counseling for nutritional supplementation before and after menopause, enriching the diet with these elements, and comprehensive nutritional assessment in the treatment of postmenopausal osteoporosis. Gür et al reported lower $\mathrm{Zn}$ and $\mathrm{Mg}$ in osteoporotic subjects, and that the addition of trace elements to the diet was efficacious in ameliorating the deficits. They also recommended the use of trace-element assessment in osteoporotic patients with normal Ca or P levels. ${ }^{35}$

Sojka and Weaver observed a significant increase in bone density and a preventive effect on fractures after 2 years of treatment with $\mathrm{Mg}(\mathrm{OH})_{2}$ in a group of postmenopausal females. ${ }^{36}$ In another study, following treatment with $\mathrm{Mg}$ for 1 year, an improvement in BMD was detected in comparison with controls. ${ }^{37}$ Steidl and Ditmar administered only $\mathrm{Mg}$ lactate to 60 patients with osteoporosis, and observed improvements in pain and spinal movements and no progression in kyphosis or X-ray findings at follow-up assessments at 6 months, 1 year, and 2 years. ${ }^{38}$

A decrease in trace elements with increasing age has been reported. Zaichick and Zaichick examined the trace elements in human iliac bone, and observed a significant decrease in the $\mathrm{Ca}, \mathrm{Mg}$, and $\mathrm{P}$ contents with increasing age ${ }^{39}$ This finding is partially in agreement with our results, which suggested that $\mathrm{Ca}, \mathrm{Mg}$, and $\mathrm{BMD}$ decreased with age. Therefore, we believe that enriching the diet with trace elements should be considered in elderly populations.

Our study suggested that in the fracture group, the sex effect was important. Zn levels were significantly lower in females than males, while Mn levels were significantly higher. Contrary to previous reports, we detected no other correlation or $\mathrm{Ca}: \mathrm{Mg}$-ratio variation according to levels of other trace elements. ${ }^{40-42}$

The determination of trace elements in living organisms, including bone tissue, is one of the main means by which bioindicators can be used to assess environmental pollution indirectly. Trace elements may not only be bioindicators of environmental exposure to metals in humans but also critical determinants of fracture risk as a result of osteoporosis. Osteoporosis and the occurrence of fractures in an elderly population are complex multifactorial situations, potentially involving genetic, metabolic, and environmental factors. It is perhaps not surprising that no strong association between elemental concentrations and the tendency to 
fracture was found. Our results support the suggestions of others: that there are systemic differences between the bones of patients with fractures and those of age-matched nonfracture patients, and that other factors determine the risk of fracture. However, we cannot exclude the possibility that trace-element accumulation at specific localized sites, eg, bone-mineralization fronts or within osteoblasts, causes problems, nor can we exclude the possibility that the causes of fracture differ among patients.

\section{Conclusion}

We found decreased bone $\mathrm{Ca}, \mathrm{Mg}$, and $\mathrm{Zn}$ contents in patients with osteoporotic fractures compared to subjects with osteoarthritis. In addition, $\mathrm{Ca}, \mathrm{Mg}$, and $\mathrm{Zn}$ decreased with age, in parallel with a reduced BMD. These results suggest that these trace elements play an important role in bone breakdown/synthesis. Although the exact role of these trace elements is still unclear, the addition of milk, milk products, or trace element-rich food sources to the diet starting from childhood and supplementation of osteoporotic patients with trace elements in addition to other therapeutic agents seems a reasonable approach. Further studies of the role of trace elements in the etiology and treatment of osteoporosis are warranted.

\section{Acknowledgments}

This study was conducted conjointly using facilities provided by the Department of Orthopedics and Traumatology, Department of Biochemistry, Department of Chemistry, and the Technology Research and Application Center, Erciyes University. It was also supported by the Scientific Research Project Commission of Erciyes University (project code TST-09-721).

\section{Disclosure}

The authors report no conflicts of interest in this work.

\section{References}

1. Raisz LG. Pathogenesis of osteoporosis: concepts, conflicts, and prospects. J Clin Invest. 2005;115(12):3318-3325.

2. Kanis JA. Assessment of fracture risk and its application to screening for postmenopausal osteoporosis: synopsis of a WHO report. WHO Study Group. Osteoporos Int. 1994;4(6):368-381.

3. Gullberg B, Johnell O, Kanis JA. World-wide projections for hip fracture. Osteoporos Int. 1997;7(5):407-413.

4. Wallach S. Relation of magnesium to osteoporosis and calcium urolithiasis. Magnes Trace Elem. 1991;10(2-4):281-286.

5. Vallee BL, Falchuk KH. The biochemical basis of zinc physiology. Physiol Rev. 1993;73(1):79-118.

6. O'Dell BL. Zinc plays both structural and catalytic roles in metalloproteins. Nutr Rev. 1992;50(2):48-50.

7. Atik OS. Zinc and senile osteoporosis. J Am Geriatr Soc. 1983;31(12): 790-791.
8. Yamaguchi M. Role of nutritional zinc in the prevention of osteoporosis. Mol Cell Biochem. 2010;338(1-2):241-254.

9. Kalisińska E, Salicki W, Mysłek P, Kavetska KM, Jackowski A. Using the mallard to biomonitor heavy metal contamination of wetlands in north-western Poland. Sci Total Environ. 2004;320(2-3):145-161.

10. Kalisińska E, Salicki W, Kavetska KM, Ligocki M. Trace metal concentrations are higher in cartilage than in bones of scaup and pochard wintering in Poland. Sci Total Environ. 2007;388(1-3):90-103.

11. Lindeman RD, Clark ML, Colmore JP. Influence of age and sex on plasma and red-cell zinc concentrations. J Gerontol. 1971;26(3):358-363.

12. Steidl L, Ditmar R, Kubícek R. [Biochemical findings in osteoporosis. I. The significance of magnesium]. Cas Lek Cesk. 1990;129(2):51-55. Czech.

13. Cohen L, Laor A, Kitzes R. Lymphocyte and bone magnesium in alcohol-associated osteoporosis. Magnesium. 1985;4(2-3):148-152.

14. Cohen L. Recent data on magnesium and osteoporosis. Magnes Res. 1988;1(1-2):85-87.

15. Mutlu M, Argun M, Kilic E, Saraymen R, Yazar S. Magnesium, zinc and copper status in osteoporotic, osteopenic and normal post-menopausal women. J Int Med Res. 2007;35(5):692-695.

16. Helliwell TR, Kelly SA, Walsh HP, et al. Elemental analysis of femoral bone from patients with fractured neck of femur or osteoarthrosis. Bone. 1996;187(2):151-157.

17. Nielsen FH. Studies on the relationship between boron and magnesium which possibly affects the formation and maintenance of bones. Magnes Trace Elem. 1990;9(2):61-69.

18. Ishii A, Imanishi Y. [Magnesium disorder in metabolic bone diseases]. Clin Calcium. 2012;22(8):1251-1256. Japanese.

19. Castiglioni S, Cazzaniga A, Albisetti W, Maier JA. Magnesium and osteoporosis: current state of knowledge and future research directions. Nutrients. 2013;5(8):3022-3033.

20. Calhoun NR. Distribution of zinc in bone tissue. J Histochem Cytochem. 1961;9:141-145.

21. Saltman PD, Strause LG. The role of trace minerals in osteoporosis J Am Coll Nutr. 1993;12(4):384-389.

22. Cerovic A, Miletic I, Sobajic S, BlagojevicD, Radusinovic M,El-Sohemy A. Effects of zinc on the mineralization of bone nodules from human osteoblast-like cells. Biol Trace Elem Res. 2007;116(1):61-71.

23. Yamada S, Inaba M. [Osteoporosis and mineral intake]. Clin Calcium. 2004;14(12):96-99. Japanese.

24. Rico H, Villa LF. Zinc, a new coherent therapy for osteoporosis? Calcif Tissue Int. 2000;67(5):422-423.

25. Thomsen JS, Nielsen PT, Christensen PH, et al. Differences in zinc status, bone turnover and femoral head bone density and biomechanical properties between patients with osteoarthritis and osteoporosis. J Musculoskelet Neuronal Interact. 2008;8(1):22.

26. Steidl L, Ditmar R. Blood zinc findings in osteoporosis. Acta Univ Palacki Olomuc Fac Med. 1990;126:129-138.

27. Matarán Pérez L, González Domínguez J, Rodríguez Pérez M, Rodrigo D, Abellán Pérez M, Salvatierra Ríos D. [Zinc and osteoporosis]. An Med Interna. 1992;9(7):331-333. Spanish.

28. Ovesen J, Møller-Madsen B, Nielsen PT, et al. Differences in zinc status between patients with osteoarthritis and osteoporosis. $J$ Trace Elem Med Biol. 2009;23(1):1-8.

29. Angus RM, Sambrook PN, Pocock NA, Eisman JA. Dietary intake and bone mineral density. Bone Miner. 1988;4(3):265-277.

30. Hyun TH, Barrett-Connor E, Milne DB. Zinc intakes and plasma concentrations in men with osteoporosis: the Rancho Bernardo Study. Am J Clin Nutr. 2004;80(3):715-721.

31. Aaseth J, Boivin G, Andersen O. Osteoporosis and trace elements - an overview. J Trace Elem Med Biol. 2012;26(2-3):149-152.

32. Lowe NM, Fraser WD, Jackson MJ. Is there a potential therapeutic value of copper and zinc for osteoporosis? Proc Nutr Soc. 2002;61(2): $181-185$.

33. Cournot MP, Hercberg S. [Prevention of mineral deficiencies (iron, calcium and magnesium)]. Rev Prat. 1993;43(2):141-145. French.

34. Tranquilli AL, Lucino E, Garzetti GG, Romanini C. Calcium, phosphorus and magnesium intakes correlate with bone mineral content in postmenopausal women. Gynecol Endocrinol. 1994;8(1):55-58. 
35. Gür A, Colpan L, Nas K, et al. The role of trace minerals in the pathogenesis of postmenopausal osteoporosis and a new effect of calcitonin. J Bone Miner Metab. 2002;20(1):39-43.

36. Sojka JE, Weaver CM. Magnesium supplementation and osteoporosis. Nutr Rev. 1995;53(3):71-74.

37. Stendig-Lindberg G, Tepper R, Leichter I. Trabecular bone density in a two year controlled trial of peroral magnesium in osteoporosis. Magnes Res. 1993;6(2):155-163.

38. Steidl L, Ditmar R. Osteoporosis treated with magnesium lactate. Acta Univ Palacki Olomuc Fac Med. 1991;129:99-106.

39. Zaichick S, Zaichick V. The effect of age and gender on 38 chemical element contents in human iliac crest investigated by instrumental neutron activation analysis. J Trace Elem Med Biol. 2010;24(1):1-6.
40. Lanocha N, Kalisinska E, Kosik-Bogacka DI, Budis H, Sokolowski S, Bohatyrewicz A. Concentrations of trace elements in bones of the hip joint from patients after hip replacement surgery. J Trace Elem Med Biol. 2012;26(1):20-25.

41. Lanocha N, Kalisinska E, Kosik-Bogacka D, Budis H, Sokolowski S, Bohatyrewicz A. Comparison of concentrations of lead and cadmium in various parts of the femur head in patients after arthroplasty of the hip joint in Northwest Poland. Biomed Environ Sci. 2012;25(5): $577-582$.

42. Budis H, Kalisinska E, Lanocha N, et al. The concentration of manganese, iron, and strontium in hip joint bone obtained from patients undergoing hip replacement surgery. J Trace Elem Med Biol. 2014;28(1):39-44.
Clinical Interventions in Aging

\section{Publish your work in this journal}

Clinical Interventions in Aging is an international, peer-reviewed journal focusing on evidence-based reports on the value or lack thereof of treatments intended to prevent or delay the onset of maladaptive correlates of aging in human beings. This journal is indexed on PubMed Central, MedLine,

\section{Dovepress}

CAS, Scopus and the Elsevier Bibliographic databases. The manuscript management system is completely online and includes a very quick and fair peer-review system, which is all easy to use. Visit http://www.dovepress. com/testimonials.php to read real quotes from published authors. 